\title{
The Protective Impacts of $\alpha$-tocopherol Supplementation on the Semen Quality of Sapera Goat Preserved at $4^{\circ} \mathrm{C}$
}

\author{
R. A. Prastiya ${ }^{\mathrm{a}, *}$, Rimayantia ${ }^{\mathrm{a}}$ M. M. Munir ${ }^{\mathrm{b}}$, \& A. P. Nugroho ${ }^{\mathrm{c}}$ \\ aDepartment of Veterinary Reproduction, Faculty of Veterinary Medicine, Universitas Airlangga \\ bStudent, Faculty of Veterinary Medicine, Universitas Airlangga \\ Jalan Mulyorejo Kampus C Universitas Airlangga 60115, Indonesia \\ cFaculty of Animal Husbandry, Universitas Jenderal Soedirman \\ Jalan Dr. Soeparno Karangwangkal, Purwokerto 53122, Indonesia \\ *Corresponding author: ragilap@fkh.unair.ac.id \\ (Received 04-06-2020; Revised 13-11-2020; Accepted 30-11-2020)
}

\begin{abstract}
Supplementation of vitamin E ( $\alpha$-tocopherol) as an antioxidant into an extender is useful to maintain sperm quality during the process of cryopreservation by protecting the sperms from reactive oxygen species (ROS). This study aims to evaluate the protective impacts of vitamin E supplementation on the motility, viability, and reducing the abnormality of sperms in Sapera goats. The sample of semen used in the present study was obtained from fresh semen and good-quality ejaculates of the Sapera goats collected by an artificial vagina. The groups involve one controlled treatment group, which contains semen and tris egg yolk (TEY) extender without vitamin E (P0), and three treatment groups that contain semen, TEY extender, and different doses of vitamin E, i.e., $1 \mathrm{mg} / \mathrm{mL}$ (P1), $2 \mathrm{mg} / \mathrm{mL}$ (P2), and 3 $\mathrm{mg} / \mathrm{mL}$ (P3), respectively. Data obtained from the experiments were analyzed using Repeated Measures Multivariate Analysis (MANOVA). The results showed that TEY extenders added with vitamin E at a dose of $1 \mathrm{mg} / \mathrm{mL}$ of vitamin E (P1) produced the highest motility and viability with the lowest abnormalities of sperm after $24^{\text {th }}$ hour of cryopreservation. The lowest sperm motility and viability among the treatment groups was observed in the TEY extender added with vitamin E at a dose of $3 \mathrm{mg} / \mathrm{mL}$ (P3) at $96^{\text {th }}$ hour after cryopreservation, which was almost the same as the control group without vitamin E (P0) that had the lowest motility and viability. In conclusion, the current study found that supplementation of vitamin $E$ as an antioxidant at a dose of $1 \mathrm{mg} / \mathrm{mL}$ in TEY extender can preserve semen of the Sapera goats in refrigerator up to $96 \mathrm{~h}$ at $4^{\circ} \mathrm{C}$ and provides higher sperm motility and viability percentage, with a lower percentage of sperm abnormality.
\end{abstract}

Keywords: vitamin E (a-tocopherol); extender; Sapera goat; sperm assessment; animal medicine

\section{INTRODUCTION}

The Sapera goat is one of the dairy goats in Indonesia, which is a crossbreed between the Saanen goat from Switzerland and the Etawah crossbreed goat (Peranakan Etawa). The crossbreed between the two goats is intended to boost both milk and meat productions with a greater carcass than the Saanen goats. The Sapera goats can produce 2 to 4 liters of milk per day during the first lactation, which is higher than the Etawah goats and the Saanen goats (Praharani et al., 2016). In order to increase the national milk production of dairy goats, it is necessary to increase the population of dairy goats, such as the Sapera goats.

One of the efforts to increase the population of the Sapera goats is through the application of artificial insemination $(\mathrm{AI})$, which allows a higher ratio of does to bucks compared to the natural breeding system. AI in goats has become a powerful method for breeders or farmers to obtain genetically-high quality offsprings by using superior bucks. Moreover, AI can also minimize the transmission of reproductive diseases and provide a more accurate birth of the offsprings (Cseh et al., 2012; Faigl et al., 2012). The success of AI using fresh semen relies on the techniques of sperm cryopreservation that semen inseminated to the female reproductive tract can reach the ovum cells (Wang et al., 2015). Various cellular and molecular damages of sperm during the cryopreservation process will affect the sperm function and fertilization potential. Decreased sperm fertilization potential during semen cryopreservation can be observed and calculated from the excessive production of reactive oxygen species (ROS) that induce cryo-injury during oxidative stress (Johnston et al., 2012; Kim et al., 2012; Liu et al., 2019). To overcome this problem, the addition of antioxidants such as vitamin $\mathrm{E}$ in the extenders during cryopreservation of semen is necessary (Sharafi et al., 2015; Forouzanfar et al., 2013a; Forouzanfar et al., 2013b; Widjaya, 2017).

Antioxidants can maintain the qualities of sperms by protecting the biological membrane from damages caused by free radicals, neutralizing hydroxyl groups, superoxide, and hydrogen peroxide radicals, as well as preventing sperm agglutination 
(Agarwal \& Prabakaran, 2005; Breininger et al., 2005). Supplementation of vitamin E into the extender will inhibit the process of lipid peroxidation reaction that helps to manage the oxidation process of phosphorylation, which is responsible for the increasing levels of Reactive Oxygen Species (ROS) in the sperm. High levels of ROS in the cells can oxidize lipids, proteins, and DNA so which can cause DNA damage, increased membrane permeability, and even reduce reproductive capacity (Noori, 2012; Paul et al., 2018; Aitken, 2017). Vitamin E can function as an intracellular antioxidant that plays an important role in preventing lipid peroxidation of unsaturated fatty acids inside the cells and on the cell membrane so that it can prevent peroxidative damage that affects spermatogenesis (Spirlandeli et al., 2014).

Information about the effect of antioxidant supplementation on Sapera buck's semen is limited from the previous studies. This gap in the literature drives us to study in vitro supplementation of Vitamin $\mathrm{E}$ in the semen extender to maintain the quality of Sapera buck semen.

\section{MATERIALS AND METHODS}

\section{Animals}

All experiments were approved by the Airlangga Health Research Ethical Clearance Committee number 011/HRECC.FODM/I. The study was conducted with three Sapera goats (2-3 years of age) with good body conditions were used and placed in hygienic and properly-ventilated sheds. The temperature inside the shed was maintained at $33-41^{\circ} \mathrm{C}$ (average $37^{\circ} \mathrm{C}$ ). The semen collection and semen analysis were carried out at the PSDKU teaching farm, Airlangga University, during the period extended from January to May 2019. The animals were supplied with clean water that was available ad libitum and were fed twice a day consisting of calliandra hay and Napier grass silage as forage, tofu (soybean curd) by-product, and commercial concentrate as feed supplement according to the nutritional requirements.

\section{Preparations of Vitamin E and Extender}

Pure Vitamin E (DL- $\alpha$-Tocopherol acetate solution (10 mM), MDL Number: MFCD00006848) used in this study was obtained from Sigma (St. Louis, MO, USA) and stored in a refrigerator at $5^{\circ} \mathrm{C}$. Prior to the addition into the semen extender, $\alpha$-tocopherol was dissolved using ethanol $0.05 \%$. Vitamin $\mathrm{E}$ was divided into 3 different concentrations ( $1 \mathrm{mg} / \mathrm{mL}, 2 \mathrm{mg} / \mathrm{mL}$, and $3 \mathrm{mg} / \mathrm{mL})$, and each concentration of vitamin $\mathrm{E}$ was mixed with the Tris-Egg-Yolk (TEY) extender. The extender material was made of Tris-Egg-Yolk obtained from the Singosari Artificial Insemination Center. Extender contains 1.6\% Tris Aminomethane, $0.9 \%$ citric acid, $1.4 \%$ lactose, $80 \%$ distilled water, $20 \%$ egg yolk, penicillin $1000 \mathrm{IU} / \mathrm{mL}$, streptomycin $1 \mathrm{mg} / \mathrm{mL}$, and vitamin E ( $\alpha$-tocopherol) according to the aforementioned doses. Antibiotics such as penicillin and streptomycin were added to the extender to suppress bacterial growth. The equipment used for this process were cleaned and sterilized. The ratio between semen and tris-egg-yolk extender was 1:10.

\section{Semen Collection}

Semen collections from 3 Sapera bucks were started with a physical examination of the reproductive organs of the bucks. The organs were healthy with a high libido. Semen collection was performed using an artificial vagina once a week in the morning with a total of one ejaculate. Fresh semen that was collected was evaluated macroscopically (volume, consistency, odor, color, and $\mathrm{pH}$ ) and microscopically (sperm motility, viability, and concentration). The standard of sperm progressive motility in this study was above or equal to $70 \%$. The sperm concentration was evaluated using a spectrophotometer.

\section{Experimental Design}

The samples used in this study were 36 semen ejaculates collected from three Sapera bucks having good fresh semen and high libido at the ages of 2-3 years old. Tris-egg yolk extender was added to the semen, with a ratio of 1:10 (semen volume to extender). The semen mixed with TEY extender was assigned into four different groups based on the different doses of vitamin $\mathrm{E}$ supplementation, namely P0 (0 mg/mL), P1 (1 mg/mL), P2 (2 mg/mL), and P3 (3 mg/mL). All samples were preserved in liquid storage at $4^{\circ} \mathrm{C}$ for 96 hours and assessed for their parameters, namely, sperm progressive motility, percent of viability, and percent of abnormalities at $24,48,72$, and 96 hours of storage.

\section{Assessment of Sperm Motility}

To evaluate the motion characteristics of rewarmed sperm, computer-assisted sperm analysis (CASA, Version 5.1; Microptic, Barcelona, Spain) was used. The evaluation was performed at $37^{\circ} \mathrm{C}$ to facilitate the optimal movement of sperms. Calculation of sperm motility was based on the speed and direction of movement. As for the direction of movement, sperms were classified into 4 categories, i.e., $\mathrm{P}$ for progressive, $\mathrm{R}$ for reverse, $\mathrm{O}$ for oscillatory, and $\mathrm{N}$ for Necrospermia or no movement, while for the speed of movement, they were categorized with a number, i.e., 0 for no movement, 1 for slow movement, 2 for moderate movement, 3 for rapid movement, and 4 for very fast movement.

\section{Assessment of Sperm Viability}

Sperm viability was assessed by using the EosinNigrosine staining method (Najafi et al., 2013). The glass slide was prepared, and then a small drop of semen $(2 \mu \mathrm{L})$ was put on the glass slide, and eosin-nigrosin $(10 \mu \mathrm{L})$ solution was put next to the semen drop. Subsequently, a thin preparation was made by fixation, and the preparation was dried for about 15 seconds. The sperm viability was assessed after fixation and drying of the preparation by calculating 200 sperm cells under bright field microscopy (CKX41; Olympus, Tokyo, 
Japan) at 400X magnifications. Live sperms remained unstained, while dead sperms were stained, turning into a red-purple color.

\section{Assessment of Sperm Abnormality}

Evaluation for abnormalities of sperm was conducted by using preparation used for viability testing (Felipe-Perez et al., 2008). At least 200 sperms were examined under a microscope with 400x magnification. Abnormal sperm were determined based on head and tail abnormalities.

\section{Statistical Analysis}

Data about motility, viability, and abnormal morphology of sperm were subsequently arranged in a table presented as average \pm SD. Multivariate (MANOVA) on SPSS version 20.0 (SPSS Inc., Chicago, IL, USA) was employed to analyze the data. If the results indicated $\mathrm{p}<0.05$, the subsequent analysis using Duncan's multiple range test was performed.

\section{RESULTS}

The quality of fresh semen of Sapera bucks is presented in Table 1 . The average volume of semen was $1.00 \pm 0.20 \mathrm{~mL}$ from the macroscopic examination, with a creamy color, a goat-smelly odor, and thick consistency that were observed by tilting the tubes. The $\mathrm{pH}$ obtained in this study was $6.60 \pm 0.54$. The standard volume of semen in goats is an average of $1 \mathrm{ml}(0.5-2$ $\mathrm{mL})$, the color of the semen is creamy white with a thick consistency, and $\mathrm{pH}$ 6.4-6.8. The initial macroscopic examination results listed in Table 1 showed the normal standards for Sapera goat semen and met the criteria for further examination.

The results of a microscopic evaluation in this study showed that the average concentration of sperms was $3876 \pm 167.57$ (million/mL). The average mass motility was (+++) marked by a large-wave formation of sperms. Furthermore, the sperms had progressive motility (forward movements) with an average of $82.80 \pm 2.16 \%$. The average result was $82 \%$, with a speed of 3-4. The average sperms viability was $89.40 \pm 4.33 \%$. The results found in this study are within the normal standard of goat sperm concentrations. Sperm abnormalities in Sapera bucks sperm ranged from $3 \%-4.5 \%$, with an average of $3.20 \pm$ 0.83 .

The effects of doses of vitamins $E$ addition in the TEY extender on the sperm characteristics (progressive sperm motility, viability, and abnormal sperm (mean \pm SD) of Sapera bucks following the preservation at $4{ }^{\circ} \mathrm{C}$ for 96 hours are presented in Table 2. Means of sperm motility and viability were significantly affected by the treatment of doses of tocopherol (Vitamin E) addition in the TEY extender. No significant difference in sperm abnormality was observed among the doses of tocopherol addition in the extender. However, semen diluted in TEY extender and added with vitamin $\mathrm{E}$ at a dose of $1 \mathrm{mg} / \mathrm{ml}$ tended to have a lower sperm abnormality. The evaluation of sperm motility showed that doses of vitamin $\mathrm{E}$ in the extender $(0 \mathrm{mg} / \mathrm{mL}, 1 \mathrm{mg} / \mathrm{mL}, 2 \mathrm{mg} /$ $\mathrm{mL}$, and $3 \mathrm{mg} / \mathrm{mL})(\mathrm{p}<0.05)$ significantly affected the sperm motility. However, looking at the more detailed comparison among the doses of vitamin E, there was no significant difference in sperm motility between semen preserved in TEY extender contained vitamin $\mathrm{E}$ at doses of 3 and $0 \mathrm{mg} / \mathrm{mL}$, and the highest motility was found in the semen preserved in TEY extender contained $1 \mathrm{mg} /$ $\mathrm{mL}$ vitamin $\mathrm{E}(\mathrm{P} 1)$. In the semen preserved in the TEY extender added with vitamin E, the sperm motilities declined gradually when preserved at $4^{\circ} \mathrm{C}$ from 24 to 96 hours to $61.30 \pm 3.88 \%$ and $28.78 \pm 3.57 \%$, respectively, compared to semen preserved in the TEY extender without vitamins (control) which was declined markedly to $47.99 \pm 2.85 \%$ and $33.75 \pm 3.57 \%$, respectively.

In terms of sperm viability, there were significant differences in the sperm viability among the doses of vitamin $\mathrm{E}$ and time of preservation $(\mathrm{p}<0.05)$. In addition, there were significant decline patterns in treatments P1, P2, P3, and P0 ( $<0.05)$. The highest sperm viability was found in semen preserved in TEY extender added with vitamin $\mathrm{E}$ at a dose of $1 \mathrm{mg} / \mathrm{mL}(\mathrm{P} 1)(\mathrm{p}<0.05)$. The results revealed that there were significant differences between $\mathrm{P} 1$ and the other treatments $(\mathrm{p}<0.05)$. Semen, preserved in TEY extender added with vitamin $\mathrm{E}$ at a dose of $1 \mathrm{mg} / \mathrm{mL}$, showed the lowest sperm abnormal-

Table 1. Ejaculates characteristics of Sapera buck semen (mean \pm standard deviation)

\begin{tabular}{|c|c|c|c|c|c|c|}
\hline \multirow{2}{*}{ Evaluation } & \multicolumn{5}{|c|}{ Repetition } & \multirow{2}{*}{ Mean \pm SD } \\
\hline & 1 & 2 & 3 & 4 & 5 & \\
\hline \multicolumn{7}{|l|}{ Macroscopy } \\
\hline Volume (mL) & 1.20 & 0.80 & 1.20 & 1.00 & 0.80 & $1.00 \pm 0.20$ \\
\hline $\mathrm{pH}$ & 7 & 7 & 6 & 7 & 6 & $6.60 \pm 0.54$ \\
\hline Consistency & Thick & Thick & Thick & Thick & Thick & Thick \\
\hline \multicolumn{7}{|l|}{ Microscopy } \\
\hline Sperm motility (\%) & 80 & 82 & 85 & 82 & 85 & $82.80 \pm 2.16$ \\
\hline Sperm concentration (million $/ \mathrm{mL}$ ) & 3720 & 3840 & 4020 & 3720 & 4080 & $3876 \pm 167.57$ \\
\hline Sperm viability $(\%)$ & 85 & 86 & 90 & 96 & 90 & $89.40 \pm 4.33$ \\
\hline Mass movement & +++ & +++ & ++ & +++ & +++ & +++ \\
\hline Sperm abnormalities (\%) & 4 & 3 & 2 & 4 & 3 & $3.20 \pm 0.83$ \\
\hline
\end{tabular}

Note: $\mathrm{SD}=$ Standard deviation. ++ = Frequent and seldom wave motion of mass sperm motility; +++= Fast and thick wave motion of mass sperm motility 
Table 2. Sperm motility, viability, and abnormality of Sapera buck treated by different vitamin E doses and time

\begin{tabular}{|c|c|c|c|c|}
\hline \multirow{2}{*}{ Vitamin E doses } & \multicolumn{4}{|c|}{ Variables (\%) (Mean \pm SD) } \\
\hline & Time & Motility & Viability & Abnormality \\
\hline \multirow[t]{4}{*}{ (P0) $0 \mathrm{mg} / \mathrm{mL}$} & 24 hours & $47.99 \pm 2.85^{\mathrm{cd}}$ & $71.22 \pm 6.19^{b}$ & $5.41 \pm 1.22^{\mathrm{b}}$ \\
\hline & 48 hours & $47.60 \pm 5.80^{\mathrm{cd}}$ & $62.20 \pm 6.19^{c}$ & $5.45 \pm 1.04^{\mathrm{b}}$ \\
\hline & 72 hours & $41.22 \pm 4.61^{\mathrm{d}}$ & $60.32 \pm 5.49^{c}$ & $5.33 \pm 1.88^{b}$ \\
\hline & 96 hours & $33.75 \pm 3.57 \mathrm{e}$ & $49.56 \pm 6.28 \mathrm{e}$ & $6.09 \pm 1.19^{b}$ \\
\hline \multirow[t]{4}{*}{ (P1) $1 \mathrm{mg} / \mathrm{mL}$} & 24 hours & $61.30 \pm 3.88^{\mathrm{a}}$ & $77.85 \pm 6.37 \mathrm{a}$ & $3.41 \pm 1.22^{\mathrm{a}}$ \\
\hline & 48 hours & $55.55 \pm 6.17^{b}$ & $70.99 \pm 8.05^{b}$ & $3.54 \pm 1.66^{\mathrm{a}}$ \\
\hline & 72 hours & $50.40 \pm 3.93^{c}$ & $60.52 \pm 5.49^{c}$ & $3.75 \pm 1.01^{\mathrm{a}}$ \\
\hline & 96 hours & $42.78 \pm 3.57^{\mathrm{d}}$ & $54.27 \pm 6.33^{\mathrm{d}}$ & $4.29 \pm 0.16^{\mathrm{ab}}$ \\
\hline \multirow[t]{4}{*}{ (P2) $2 \mathrm{mg} / \mathrm{mL}$} & 24 hours & $49.30 \pm 3.80^{c}$ & $70.33 \pm 4.33^{b}$ & $5.01 \pm 1.22^{\mathrm{b}}$ \\
\hline & 48 hours & $42.40 \pm 6.64^{\mathrm{d}}$ & $60.17 \pm 9.01^{c}$ & $5.95 \pm 1.66^{\mathrm{b}}$ \\
\hline & 72 hours & $39.40 \pm 4.02^{\mathrm{de}}$ & $57.50 \pm 5.22^{\mathrm{cd}}$ & $5.33 \pm 1.09^{b}$ \\
\hline & 96 hours & $30.78 \pm 2.99 e$ & $48.20 \pm 5.09 \mathrm{e}$ & $5.29 \pm 1.04^{\mathrm{b}}$ \\
\hline \multirow[t]{4}{*}{ (P3) $3 \mathrm{mg} / \mathrm{mL}$} & 24 hours & $48.56 \pm 2.58^{c}$ & $71.85 \pm 6.29^{b}$ & $4.48 \pm 1.22^{\mathrm{ab}}$ \\
\hline & 48 hours & $49.28 \pm 5.91^{c}$ & $60.42 \pm 8.67 c$ & $5.22 \pm 1.53^{b}$ \\
\hline & 72 hours & $39.40 \pm 4.33^{\mathrm{de}}$ & $59.50 \pm 6.49^{c}$ & $5.65 \pm 1.11^{b}$ \\
\hline & 96 hours & $28.78 \pm 3.57 \mathrm{e}$ & $47.24 \pm 6.00^{\mathrm{e}}$ & $6.22 \pm 0.99^{b c}$ \\
\hline
\end{tabular}

Note: Means in the same column with different superscripts differ significantly $(\mathrm{p}<0.05)$. Control $(\mathrm{P} 0)=\mathrm{No}$ addition of vitamin E; P1= addition of $1 \mathrm{mg} /$ $\mathrm{mL}$ vitamin $\mathrm{E}$ to the extender; $\mathrm{P} 2=$ addition of $2 \mathrm{mg} / \mathrm{mL}$ vitamin $\mathrm{E}$ to the extender; $\mathrm{P} 3=$ addition of $3 \mathrm{mg} / \mathrm{mL}$ vitamin $\mathrm{E}$ to the extender, respectively.

ity. Subsequent analysis was conducted to evaluate the effect of time, i.e., at $4^{\circ} \mathrm{C}$ preservation for $24,48,72$, and 96 hours, on the motility, viability, and abnormalities of spermatozoa. The results showed a significant effect of time on motility, as was shown by the significant difference among the $24^{\text {th }}, 48^{\text {th }}, 72^{\text {nd }}$, and $96^{\text {th }}$ hours after freezing $(\mathrm{p}<0.05)$. Furthermore, the results of the viability analysis showed a significant difference between the $24^{\text {th }}$ and $48^{\text {th }}$ hours, and between the $72^{\text {nd }}$ and $96^{\text {th }}$ hours $(p<0.05)$, and a significant decrease in patterns between the $24^{\text {th }}, 48^{\text {th }}, 72^{\text {th }}$, and $96^{\text {th }}$ hours $(\mathrm{p}<0.05)$.

Finally, from the two initial parameters, the motility and viability, vitamin E's addition at a dose of $1 \mathrm{~g} /$ $\mathrm{mL}$ (P1) showed the best results to Sapera bucks semen diluted with TEY on sperm quality.

\section{DISCUSSION}

Sperm motility is powered by cellular energy production, which is resulted from oxidative phosphorylation and is transferred into the microtubules in the tail to stimulate and support tail movements ( $\mathrm{O}^{\prime}$ Connell et al., 2002). There are two main pathways of energy production in the sperm, namely glycolysis and oxidative phosphorylation (Storey, 2008). The previous research shows that oxidative phosphorylation is more effective in energy production for mammalian sperm (Tafif, 2019). The process of oxidative phosphorylation occurs in the mitochondria through the electron transport chain. Sperm mitochondria are located in the central part, and energy production takes place in the gyre (Gibb \& Aitken, 2016). ROS are formed during the process of oxygen reduction in oxidative phosphorylation. Although the ROS binding system exists in the electron transport chain, electron leakage by previous components can still occur (Halliwell \& Gutteridge, 2015).
The cooling process reduces membrane fluidity, sperm motility, and speed (Fang et al., 2017). Cryopreservation also decelerates the metabolic rate in the sperm. However, a decrease in metabolic rate cannot stop cells from producing ROS (Gibb \& Aitken, 2016; Prastiya et al., 2019). The previous results of a study suggested that decreased sperm motility and mitochondrial function were found in refrigerated semen and mitochondrial dysfunction is a major cause of decreased sperm motility (O'Connell et al., 2002; Tafif, 2019).

The positive outcomes of vitamin E supplementation in domestic animals have been widely studied, including in a sample of goats (Azawi \& Hussein, 2013). Adding vitamin $E$ to the semen extender also results in improving the male's fertility parameters (Hadi, 2016). Sperm membranes are mostly composed of Polyunsaturated Fatty Acids (PUFA) that makes the sperm is very susceptible to lipid peroxidation. Vitamin E supplementation helps in maintaining the sperm motility of cooled semen of bulls (Ratnani et al., 2017). This helps in finding free radicals created from lipid peroxidation by creating two new stable radicals from one vitamin E molecule (Hajibabaei, 2016). Vitamin E has lipophilic properties (Azzi, 2007). Therefore, the percentage of lipids in the structure of sperm and lipid compounds from semen extender can influence the amount of vitamin E required for supplementation. In this study, high vitamin E concentrations showed a detrimental effect in maintaining motility, presumably because the formation of free radicals from metal reduction is facilitated by the high doses of vitamin E (Khorramabadi et al., 2017). These metals are Fe and Cu (Halliwell \& Gutteridge, 2015), which are contained in large quantities in the seminal plasma (Hardijanto et al., 2010). In the previous studies, the effect of supplementation of vitamin $\mathrm{E}$ with concentrations of $1.50 \mathrm{mg}$ 
and $1 \mathrm{mg} / \mathrm{mL}$ in bull semen increases the percentage of sperm motility (Ullah et al., 2019). These findings are similar to data reported in various species of mammals, including in bulls, Murrah buffaloes, and cattle families (Ullah et al., 2019). These results indicate that vitamin E supplementation can maintain sperm motility during cryopreservation. The low antioxidant content of seminal plasma also decreases sperm motility, viability, and normal morphology (Am-in et al., 2011). Vitamin E, which presents in the mammalian cell membranes and seminal plasma, cleanses ROS and consequently relieves oxidative stress (Sikka, 2004). The implementation of synthetic analogs of vitamin E also substantially protects membrane ultrastructure and improves intact plasma and mitochondrial membranes (Soares et al., 2015).

Reactive oxygen is generated by leakage of the electron transport chain of the mitochondria and can also be resulted from damages in the mitochondrial structure (Halliwell \& Gutteridge, 2015). ROS also impairs the mitochondria of sperm, creating multiple amounts of ROS production. They bind PUFA hydrogen and produce lipid peroxyl radicals that will bind the adjacent PUFA molecules, producing lipid peroxide and an alkyl radical. This cycle is known as a chain reaction (Hajibabaei, 2016).

An antioxidant supplement that can supply hydrogen atoms to ROS is necessary to prevent chain reactions. $\mathrm{OH} \alpha$-tocopherol actively supplies hydrogen atoms (Herdis et al., 2013). Therefore, such antioxidants can be promising to prevent oxidative damage such as lipid peroxidation (Maya et al., 2012). Vitamin E is also known as a chain-breaking antioxidant because it provides its hydrogen atom and forms alphatocopheroxyl radicals that will react with the second free radical. Therefore, a single molecule of $\alpha$ - tocopherol will consume two free radicals in the total (Hajibabaei, 2016). However, the percentage of lipids in the environment affects the solubility of vitamin E, a lipophilic antioxidant that directly affects the lipid domain. The amount of lipid content differs between semen extender and sperm architecture. Therefore, the effect of the dose of vitamin E supplementation can differ depending on the content of the extender and animal species (Azzi, 2007). According to Khorramabadi et al. (2019), vitamin E shows a pro-oxidant activity, so that vitamin E may be useful for eliminating complications resulting from oxidative stress. In this study, the evaluation of results produced by the addition of vitamin $\mathrm{E}$ at a dose of $3 \mathrm{mg} /$ $\mathrm{mL}$ (P3) suggests that high vitamin E supplementation concentrations can bring a detrimental effect. This is likely due to the ability of vitamin $\mathrm{E}$ to reduce $\mathrm{Fe}$ and $\mathrm{Cu}$ (Halliwell \& Gutteridge, 2015).

\section{CONCLUSION}

In conclusion, the current study found that supplementation of vitamin $\mathrm{E}$ as an antioxidant at a dose of $1 \mathrm{mg} / \mathrm{mL}$ in TEY extender can preserve semen of the Sapera goats in a refrigerator up to $96 \mathrm{~h}$ at $4^{\circ} \mathrm{C}$ and provides higher sperm motility and viability percentage, and a lower sperm abnormality percentage.

\section{CONFLICT OF INTEREST}

The authors declare that they have no competing interests.

\section{ACKNOWLEDGEMENT}

The authors are thankful to the Dean of Faculty of Veterinary Medicine and the Coordinator PSDKU Airlangga University (Universitas Airlangga) for approval of research work with SK no.1185/UN3/2018.

\section{REFERENCES}

Agarwal, A. \& S. A. Prabakaran. 2005. Oxidative stress and antioxidants in male infertility: A difficult balance. Iran. J. Reprod. Med. 3:1-8.

Aitken, R. J. 2017. Reactive oxygen species as mediators of sperm capacitation and pathological damage. Mol. Reprod. Dev. 84:1039-1052. https://doi.org/10.1002/mrd.22871

Am-In, N., R. Kirkwood, M. Techakumphu, \& W. Tantasuparuk. 2011. Lipid profiles of sperm and seminal plasma from boars having normal or low sperm motility. Theriogenology 75:897-903. https://doi.org/10.1016/j. theriogenology.2010.10.032

Am-In, N., R. Kirkwood, M. Techakumphu, \& W. Tantasuparuk. 2010. Effect of storage for $24 \mathrm{~h}$ at $18^{\circ} \mathrm{C}$ on sperm quality and a comparison of two assays for sperm membrane lipid peroxidation. Can. J. Anim. Sci. 90:389392. https://doi.org/10.4141/CJAS09122

Azzawi, O. I. and E. K. Hussein. 2013. Effect of vitamins C or E supplementation to tris diluent on the semen quality of Awassi rams preserved at $5^{\circ} \mathrm{C}$. Vet. Res. Forum. 4:157-160.

Azzi, A. 2007. Molecular mechanism of alpha-tocopherol action. Free. Radic. Biol. Med. 43:16-21. https://doi.org/10.1016/j. freeradbiomed.2007.03.013

Breininger, E., N. B. Beorlegui, C. M. O'Flaherty, \& M. T. Beconi. 2005. Alpha-tocopherol improves biochemical and dynamic parameters in cryopreserved boar semen. Theriogenology 63:2126-2135. https://doi. org/10.1016/j.theriogenology.2004.08.016

Cseh, S., V. Faigl, \& G. S. Amiridis. 2012. Amiridis, semen processing and artificial insemination in health management of small ruminants. Anim. Reprod. Sci. 130:187-192. https://doi.org/10.1016/j.anireprosci.2012.01.014

Faigl, V., N. Vass, A. Javor, M. Kulcsar, L. Solti, G. Amiridis, \& S. Cseh. 2012. Artificial insemination of small ruminants: A review. Acta Vet. Hung. 60: 115-129. https://doi. org/10.1556/AVet.2012.010

Fang, Q., J. Wang, Y. Y. Hao, H. Li, J. X. Hu, \& G. S. Yang. 2017. Effects of iodine methionine on boar sperm quality during liquid storage at $17^{\circ} \mathrm{C}$. Reprod. Domest. Anim. 52: 10611066. https://doi.org/10.1111/rda.13024

Felipe-Perez, Y. E., M. L. Juarez-Mosqueda, E. O. HernandezGonzalez, \& J. J. Valencia. 2008. Viability of fresh and frozen bull sperm compared by two staining techniques. Acta Vet. Bras. 2:123-130.

Forouzanfar, M., A. Abid, S. M. Hosseini, M. Hajian, \& M. H. N. Esfahani. 2013a. Supplementation of sperm cryopreservation media with cell permeable superoxide dismutase mimetic agent (MnTE) improves goat blastocyst formation. Cryobiology. 67:394-397. https://doi.org/10.1016/j. cryobiol.2013.08.004

Forouzanfar, M., S. F. Ershad, S. M. Hosseini, M. Hajian, S. Ostad-Hosseini, A. Abid, M. Tavalaee, A. Shahverdi, A. V. Dizaji, \& M. H. N. Esfahani. 2013b. Can permeable super oxide dismutase mimetic agents improve the quality of frozen-thawed ram semen?. Cryobiology 66:126-130. 
https://doi.org/10.1016/j.cryobiol.2012.12.006

Gibb Z. \& R. J. Aitken. 2016. The impact of sperm metabolism during in vitro storage: the stallion as a model. Biomed Res. Int. 2016:1-8. https://doi.org/10.1155/2016/9380609

Hadi, I. H. 2016. Effect of vitamin E on sperm motility and survival in chilled-stored semen. Iraqi Journal of Embryo and Infertility Researches. 6:1-7.

Hajibabaei, K. 2016. Antioxidant properties of vitamin E. Ann. Res. Antioxid. 1:e22.

Halliwell, B. \& J. M. C. Gutteridge. 2015. Free radicals in biology and medicine, $5^{\text {th }}$ ed. Oxford, Oxford University Press.

Hardijanto, S. Susilowati, T. Hernawati, T. Sardjito, T. W. Suprayogi. 2010. Buku Ajar Inseminasi Buatan. $1^{\text {st }}$ ed. Pusat Penerbitan dan Percetakan Unair, Surabaya.

Herdis, H., I. Kusuma, \& D. I. W. Angga. 2013. Pengaruh penambahan a-tokoferol pada media pengencer tris kuning telur terhadap kualitas semen cair domba garut (Indonesian). Jurnal Sains dan Teknologi Indonesia. 11:175-180. https:// doi.org/10.29122/jsti.v11i3.836

Johnston, S. D., N. Satake, Y. Zee, C. Lopez-Fernandez, W.V. Holt, \& J. Gosalvez. 2012. Osmotic stress and cryoinjury of koala sperm: An integrative study of the plasma membrane, chromatin stability and mitochondrial function. Reproduction. 143:787-797. https://doi.org/10.1530/ REP-11-0436

Khorramabadi, K. M., A. A. Sarcheshmeh, A. R. Talebi, \& A. Mirjalili. 2019. Protective effect of vitamin E on oxidative stress and sperm apoptosis in diabetic mice. Int. J. Reprod. Biomed. 17:127-134. https://doi.org/10.18502/ijrm. v17i2.3990

Kim, S., C. Agca, \& Y. Agca. 2012. Changes in rat sperm function after cooling, cryopreservation and centrifugation processes. Cryobiology. 65:215-223. https://doi.org/10.1016/j. cryobiol.2012.06.006

Liu T., Y. Han, T. Zhou, R. Zhang, H. Chen, S. Chen, \& H. Zhao. 2019. Mechanisms of ROS-induced mitochondria dependent apoptosis underlying liquid storage of goat spermatozoa. Aging. 18:7880-7898. https://doi.org/10.18632/ aging.102295

Maya, W., K. Mayur, \& S. Ashar. 2012. Pharmaceutical profile of alpha-tocopherol: A brief review. Int. J. Pharm. Chem. Sci. 1:1023-1039

Najafi, A., M. Zhandi, A. Towhidi, M. Sharafi, A. A. Sharif, M. K. Motlagh, \& F. Martinez-Pastor. 2013. Trehalose and glycerol have a dose-dependent synergistic effect on the post-thawing quality of ram semen cryopreserved in a soybean lecithin-based extender. Cryobiology 66:275-282. https://doi.org/10.1016/j.cryobiol.2013.03.002

Noori, S. 2012. An overview of oxidative stress and antioxidant defensive system. J. Clin. Cell. Immunol. 1:1-9. https://doi. org/10.4172/scientificreports.413

O'Connell, M., N. McClure, \& S. E. Lewis. 2002. The effects of cryopreservation on sperm morphology, motility and mitochondrial function. Hum. Reprod. 17:704-709. https:// doi.org/10.1093/humrep/17.3.704

Paul, R. K., K. Balaganur, S. V. Bahire, D. Kumar, \& R. Singh. 2018. Supplementation of cauda epididymal plasma improves sperm characteristics following liquid preservation of ram semen at $3-5^{\circ} \mathrm{C}$. Reprod. Fertil. Dev. 30:13891401. https://doi.org/10.1071/RD18063

Praharani, L., S. Supriyati, \& R. Krisnan. 2016. A preliminary study on some reproductive traits and heterosis effects of Anglo Nubian and Etawah grade crossbred does. Indonesian Center for Animal Research and Development (ICARD), Indonesia. pp. 252-260. https://doi.org/10.14334/ Proc.Intsem.LPVT-2016-p.252-260

Prastiya, R. A., A. Samik, M. T. E. Purnama, \& A. L. Saputro. 2019. Protective effect of mycotoxin binders on ovarian gestation mice exposed by zearalenone. Indian Vet. J. 96:44-46.

Ratnani, H., M. N. Ihsan, G. Ciptadi, \& S. Suyadi. 2017. Effect of alpha- tocopherol supplementation in the extender on the sperm quality of Maduran bull before and after quick freezing. Int. J. Adv. Res. 5:1378-1389. https://doi. org/10.21474/IJAR01/4849

Sharafi, M., M. Zhandi, A. Shahverdi, \& M. Shakeri. 2015. Beneficial effects of nitric oxide induced mild oxidative stress on post-thawed bull semen quality. Int. J. Fertil. Steril. 29:230-237. https://doi.org/10.22074/ijfs.2015.4244

Sikka, S. 2004. Role of oxidative stress and antioxidants in andrology and assisted reproductive technology. J. Androl. 25:5-18. https://doi.org/10.1002/j.1939-4640.2004.tb02751.x

Soares, A. T., S. V. Silva, A. M. Batista, F. C. Almeida, J. F. Nunes, C. A. Peixoto, \& M. M. P. Guerra. 2015. Ultrastructure evaluation of goat sperm after freezing in a skim milkbased extender with Trolox supplementation. Andrologia 47:470-476. https://doi.org/10.1111/and.12279

Spirlandeli, A. L., R. Deminice, \& A. A. Jordao. 2014. Plasma malondialdehyde as biomarker of lipid peroxidation: effects of acute exercise. Int. J. Sports Med. 35:14-18. https:// doi.org/10.1055/s-0033-1345132

Storey, B. T. 2008. Mammalian sperm metabolism: Oxygen and sugar, friend and foe. Int. J. Dev. Biol. 52:427-437. https:// doi.org/10.1387/ijdb.072522bs

Tafif, K. 2019. The effect of alpha-tocopherol supplementation in skim milk extender of sapudi ramon on sperm motility, viability, plasma membrane integrity, and cromatin damage. Dissertation, Airlangga University.

Ullah, Z., H. Khan, S. M. Hussain, M. T. Tunio, S. M. R. Dilshad, A. Gohar, H. Zahid, \& A. Ali. 2019. Enhancement of extender excellence of frozen bull semen using $\alpha$-Tocopherol as an antioxidant. Acta Sci. Vet. 47:1641. https://doi. org/10.22456/1679-9216.90447

Wang, W., J. Luo, S.Sun, L. Xi, Q. Gao, A.B. Haile, H. Shi, W. Zhang, \& H. Shi. 2015. The effect of season on sperm motility, plasma membrane and acrosome integrity in fresh and frozen-thawed Semen from Xinong Saanen Bucks. Reprod. Domest. Anim. 250:23-28. https://doi.org/10.1111/ rda.12444

Widjaya, N. 2017. Pengaruh pemberian susu skim dengan pengencer tris kuning telur terhadap daya tahan hidup sperm sapi pada suhu penyimpanan $5^{\circ} \mathrm{C}$ (Indonesian). Sains Peternakan: Jurnal Penelitian Ilmu Peternakan. 9:72-76. https://doi.org/10.20961/sainspet.9.2.72-76 